\title{
PENGARUH KEMENARIKAN ALTERNATIF DAN BIAYA BERPINDAH TERHADAP NIAT BERALIH PENGGUNA KARTU XL AXIATA
}

\author{
Alya E. Sjioen ${ }^{1}$,Inggrid Febrianty Makaweru² \\ ${ }^{1,2}$ Fakultas Ekonomi, Universitas Kristen Artha Wacana Kupang \\ Corresponding author : litasjioen@gmail.com
}

\begin{abstract}
ABSTRAK
Penelitian ini bertujuan untuk mengetahui pengaruh kemenarikan alternatif dan biaya berpindah terhadap niat beralih pengguna kartu XL Axiata pada mahasiswa Universitas Kristen Artha Wacana Kupang. Latar belakang dari penelitian ini adalah semakin beragamnya provider kartu seluler yang ditawarkan di Indonesia yang menunjukkan bahwa provider kartu seluler Telkomsel memiliki jumlah pelanggan terbesar sedangkan jumlah pelanggan terendah adalah provider kartu seluler XL Axiata. Oleh karena itu, operator seluler XL Axiata perlu mewaspadai masalah ini agar pelanggan mereka tidak berpindah ke operator lainnya. Hal ini menjadi peringatan bagi XL Axiata untuk mengevaluasi apa saja yang mempengaruhi pelanggan untuk memilih produk lain dibanding XL Axiata sehingga mereka memiliki jumlah pelanggan yang sedikit. Sehingga persoalan dalam penelitian ini adalah apakah kemenarikan alternatif berpengaruh terhadap niat beralih pengguna kartu XL Axiata dan apakah biaya berpindah berpengaruh terhadap niat beralih pengguna kartu XL Axiata. teknik pengumpulan data berupa pembagian kuesioner melalui google form kepada mahasiswa Universitas Kristen Artha Wacana Kupang. Penelitian ini menunjukkan bahwa secara statistik terbukti bahwa kemenarikan alternatif berpengaruh positif terhadap niat beralih pengguna kartu XL Axiata dan biaya berpindah berpengaruh positif terhadap niat beralih pengguna kartu XL Axiata. Dengan demikian, semakin tinggi kemenarikan alternatif atau daya tarik positif yang dimiliki operator lain maka semakin tinggi niat pengguna kartu XL Axiata untuk beralih. Dan dalam penelitian ini juga menunjukkan bahwa walaupun semakin tinggi biaya berpindah tidak akan menghambat artinya semakin tinggi niat pengguna kartu XL Axiata untuk tetap melakukan perpindahan karena harga yang ditawarkan sesuai dengan pelayanan yang diberikan.
\end{abstract}

Kata kunci : Kemenarikan Alternatif, Biaya Berpindah, Niat Beralih

\section{PENDAHULUAN}

Dengan perkembangan era digital yang semakin meningkat setiap tahunnya telah menimbulkan dampak kepada industri telekomunikasi seluler di Indonesia. Industri telekomunikasi seluler merupakan salah satu industri terbesar yang memiliki peranan penting dalam pembangunan ekonomi bagi suatu negara. Perkembangan industri telekomunikasi di Indonesia saat ini yang terus meningkat mengakibatkan persaingan dalam industri telekomunikasi khususnya antar provider kartu seluler menjadi sangat kompetitif. Peningkatan tersebut ditunjukkan dengan semakin banyak dan beragamnya produk kartu seluler. Hal itu dibuktikan juga dengan adanya pemberian fasilitas dan kemudahan yang ditawarkan kepada pelanggan dalam berkomunikasi. Selain itu, semakin beragam dan murahnya tarif telepon, sms, dan layanan data yang ditawarkan oleh tiap operator seluler, serta semakin banyak iklan yang ditayangkan melalui media cetak dan elektronik oleh beberapa operator seluler.

Banyaknya provider kartu seluler yang ditawarkan tersebut dapat menyebabkan beragamnya pilihan bagi konsumen (Ariani, 2012:1). Dari fenomena persaingan tersebut, 
dapat ditunjukkan bahwa konsumen memiliki pilihan yang banyak dalam memenuhi kebutuhan untuk berkomunikasi. Semakin banyak provider kartu seluler prabayar yang di tawarkan oleh operator, maka akan menuntut operator-operator telekomunikasi lainnya untuk terus menerus memberikan produk dan layanan berkualitas yang dapat meningkatkan kekuatan produk mereka. Hal ini akan memungkinkan konsumen untuk berpindah dari satu provider kartu seluler ke provider kartu seluler lainnya (Ariani, 2012: 2). Indonesia memiliki dua jaringan telepon seluler yaitu GSM dan CDMA dengan lima jenis tipe kartu seluler. Kartu seluler berbasis GSM diantaranya Telkomsel yang merek dagangnya yaitu simPATI, Kartu As dan Halo, Indosat dengan merek IM3, Mentari dengan mereknya adalah Matrix , XL Axiata dengan mereknya XL Prabayar, Hutchinson dengan merek dagangnya 3 (Three), serta Natrindo Telepon Selular (NTS) dengan mereknya adalah Axis. Sedangkan lima operator kartu seluler berbasis CDMA diantaranya Bakrie Telecom dengan merek Esia, Smart Telecom dengan merek yaitu Smart, Mobile-8, Sampoerna Telecom dan Telkom Flexi. Dari semua merek dagang operator kartu seluler tersebut terdapat empat merek dagang yang biasanya paling banyak digunakan dengan memiliki jumlah pelanggan yang berbeda-beda. Hal ini dapat terjadi karena jangkauan jaringan XL Axiata di Indonesia tidak seluas pesaingnya. Oleh karena itu, XL Axiata menggunakan strategi cost leadership untuk dapat bertahan ditengah persaingan.

Strategi cost leadership merupakan upaya mendapatkan keunggulan kompetitif dengan meningkatkan penjualan melalui persaingan harga terendah. Dari hal tersebut penulis ingin mengkaji apakah strategi biaya rendah yang digunakan XL Axiata dapat bersaing dengan operator lain yang lebih memiliki daya tarik positif pada produknya dan apakah daya tarik operator lain tersebut dapat mempengaruhi niat pelanggan untuk berpindah ke operator yang kualitas layanannya lebih baik . Dan juga untuk melihat apakah switching cost (dalam hal ini biaya yang lebih mahal) yang harus dibayarkan pelanggan jika berpindah ke operator lain dapat mempengaruhi niat pelanggan untuk berpindah ataukah tidak mempengaruhi niat pelanggan untuk berpindah. Maka, penulis memfokuskan pada provider kartu XL Axiata yang mana dapat diketahui bersama bahwa XL menjadi perusahaan swasta pertama di Indonesia yang menyediakan layanan telepon selular. XL dikenal sebagai pelopor layanan selular kepada anggota masyarakat biasa di Indonesia melalui program tarif hemat -Rp1/detik\| pada tahun 2007, yang memungkinkan lebih banyak penduduk berpenghasilan menengah ke bawah menikmati layanan telepon selular dengan infrastruktur jaringan dan layanan yang sangat luas di seluruh tanah air termasuk provinsi Nusa Tenggara Timur dalam hal ini Kota Kupang. Dengan banyaknya pilihan provider kartu seluler yang menawarkan banyak pilihan layanan komunikasi tersebut membuat tingkat perpindahan pelanggan dapat menjadi tinggi Oleh karena itu, operator seluler XL Axiata perlu mewaspadai masalah ini agar pelanggan mereka tidak berpindah ke operator lainnya. Hal ini menjadi peringatan bagi XL Axiata untuk mengevaluasi faktor-faktor yang membuat menurunnya jumlah pelanggan tersebut. Maka perusahaan perlu untuk mencari solusi dalam mengatasi hambatan-hambatan yang mengikat pelanggan agar pelanggan tetap menggunakan produk dan jasa mereka. Hambatan-hambatan inilah yang disebut dengan niat beralih konsumen.

\section{LANDASAN TEORI DAN PENGEMBANGAN HIPOTESIS Niat Beralih}

Niat atau intensi adalah perilaku konsumen yang mengacu pada orientasi dimasa depan dengan cara diantisipasi dan direncanakan. Para pemasar dalam hal ini harus dapat memahami niat konsumen terutama yang berkaitan dengan perilaku membeli. Dalam pemasaran, niat seringkali didorong oleh berbagai macam rencana yang berkaitan dengan produk atau jasa yang baru diantaranya adalah pasti akan membeli, mungkin akan membeli, belum 
memutuskan, mungkin tidak akan membeli, dan pasti tidak akan membeli (Churchill Jr,2005:291). Sedangkan menurut Keaveney dan Parthasarathy (2001), mereka berpendapat bahwa beralih atau berpindah merupakan perilaku dimana konsumen berpindah dari satu penyedia jasa ke penyedia jasa lain. Selain itu, menurut Santonen (dalam Siddiqui,2011) menyatakan bahwa dalam pemasaran produk dan jasa, perilaku perpindahan atau perilaku beralih tersebut dapat bersifat total atau parsial. Perpindahan total merupakan perpindahan yang mudah untuk dideteksi, artinya bahwa konsumen mendekati seluruh jasa yang ada dan memilih penyedia jasa lain bagi kebutuhan mereka dimasa datang (Colgate dan Hedge, 2001). Sedangkan perpindahan parsial merupakan perpindahan yang disebabkan oleh hilangnya bagian bisnis pelanggan dan hal ini lebih sulit untuk dideteksi dibanding perpindahan total (Reichheld, 1996). Perpindahan parsial dapat terjadi dalam dua cara yaitu pelanggan dapat bergeser ke penyedia jasa lain dan pelanggan dapat menggunakan jasa tambahan,tetapi dari penyedia jasa lain (Siddiqui, 2011a: 364). Sehingga Bansal et al. (2005) berpendapat bahwa niat beralih (switching intention) merupakan tingkat kemungkinan atau kepastian bahwa pelanggan akan berpindah dari penyedia jasa atau produk saat ini kepada penyedia jasa atau produk baru. Niat beralih berkaitan dengan konsep keinginan untuk berperilaku, yang dibangun atas sikap konsumen terhadap objek dan perilaku sebelumnya (Taufiq, 2007).

Konsep niat beralih (switching intention) juga dikemukakan oleh Nelloh dan Liem (2011:26) yang berpendapat bahwa seseorang mungkin atau pasti melakukan perpindahan yakni pengguna rumah kos akan berpindah dari penyedia jasa rumah kos saat ini kepada penyedia jasa rumah kos yang baru dengan diukur berdasarkan tingkat harapan yang kuat untuk berpindah kerumah kos yang lain, tingkat keinginan berpindah kerumah kos yang lain dan memiliki rencana yang matang untuk berpindah kerumah kos yang lain. Papalapu (2015) menyatakan pengertian niat beralih konsumen adalah perilaku konsumen yang memiliki kecenderungan untuk beralih ke produk lain disebabkan karena banyak keinginan atau kebutuhan konsumen, sehingga konsumen akan terus mencari dan menemukan produk yang mampu memenuhi keinginan atau kebutuhan mereka. Dari berbagai pengertian diatas, Bansal et al (2005) menguraikan beberapa faktor yang mempengaruhi perpindahan pelanggan atau niat beralih dan mengelompokkannya dalam tiga faktor sebagai berikut :

a. Faktor pendorong (push factors) adalah faktor yang mendorong konsumen untuk melakukan perpindahan terdiri dari kualitas pelayanan yang rendah, kepuasan yang rendah, nilai yang rendah, kepercayaan yang rendah, komitmen yang rendah, dan persepsi harga tinggi.

b. Faktor penarik (pull factors) adalah faktor yang menarik konsumen untuk melakukan perpindahan terdiri dari kemenarikan alternatif

c. Faktor penambat (mooring factors) adalah faktor yang menghambat konsumen untuk melakukan perpindahan terdiri dari sikap yang tidak menguntungkan terhadap perpindahan, norma subjektif yang tidak menguntungkan, biaya berpindah, perilaku perpindahan yang jarang terjadi, dan mencari variasi yang rendah.

Jadi, penulis mendapat pemahaman baru berdasarkan faktor-faktor diatas bahwa faktor tersebut dapat diuraikan lagi menjadi dua faktor yang menyebabkan terjadinya niat beralih konsumen. Faktor-faktor yang penulis kemukakan antara lain adalah : Faktor positif, yaitu faktor yang secara positif mendukung konsumen untuk memiliki niat beralih atau melakukan perpindahan produk maupun jasa. Dalam faktor positif dibagi lagi menjadi dua faktor yaitu (a) Faktor positif yang timbul dari produk atau jasa itu sendiri diantaranya kualitas pelayanan yang rendah, kepuasan yang rendah, nilai yang rendah, kepercayaan yang rendah, komitmen yang rendah, dan persepsi harga tinggi. (b) Faktor positif yang timbul dari produk atau jasa lain terdiri dari kemenarikan alternatif yang dimiliki produk lain seperti kualitas pelayanan produk lain yang lebih bagus, nilai yang dimiliki produk lain lebih bagus, kepercayaan dan komitmen lebih bagus, dan persepsi harga rendah sehingga menarik 
konsumen untuk beralih. Faktor kedua adalah faktor negatif adalah faktor yang secara negatif tidak mendukung konsumen untuk memiliki niat beralih atau melakukan perpindahan produk maupun jasa. Faktor ini terdiri dari sikap yang tidak menguntungkan terhadap perpindahan, norma subjektif yang tidak menguntungkan, biaya berpindah, perilaku perpindahan yang jarang terjadi, dan mencari variasi yang rendah. Sehingga berdasarkan pemaparan penulis diatas, penulis menyimpulkan bahwa Faktor pendorong (push factors) dan Faktor penarik (pull factors) yang dikemukakan Bansal termasuk dalam faktor positif. Sedangkan Faktor penambat (mooring factors) termasuk dalam faktor negatif seperti yang dikemukakan penulis. Dan faktor-faktor tersebut dapat mempengaruhi niat konsumen untuk beralih

Disisi lain, Wibowo (2013) juga menyatakan bahwa kemenarikan alternatif, biaya berpindah, hubungan interpersonal, dan pemulihan layanan merupakan faktor-faktor yang mempengaruhi niat beralih konsumen. Menurut Lucas dan Britt (dalam Setiani, 2019:35) mengemukakan bahwa indikator yang terdapat dalam niat beralih atau intensi berpindah adalah sebagai berikut :

a. Perhatian merupakan sikap konsumen yang memiliki perhatian lebih terhadap suatu produk barang atau jasa

b. Ketertarikan merupakan sikap konsumen setelah adanya perhatian timbul rasa tertarik terhadap suatu produk barang atau jasa

c. Keinginan merupakan sikap konsumen yang berlanjut setelah perhatian dan tertarik kemudian memiliki keinginan untuk memiliki suatu produk barang atau jasa

d. Keyakinan merupakan sikap konsumen dimana timbul keyakinan pada diri individu terhadap produk barang atau jasa tersebut sehingga muncul niat untuk memperolehnya.

\section{Kemenarikan Alternatif}

Kemenarikan alernatif merupakan tingkatan mengenai sesuatu dalam hal ini produk barang maupun jasa yang lebih buruk atau lebih baik berdasarkan berbagai perspektif konsumen akan produk barang dan jasa tersebut (Julander dan Soderlund, 2003:20). Disisi lain menurut Sulistiyani (2006) berpendapat bahwa kemenarikan alternatif adalah perspektif konsumen yang berpikir bahwa lebih baik berpindah ke layanan produk yang lebih memuaskan daripada menerima layanan dari penyedia produk yang tidak memuaskan. Pendapat lain mengenai kemenarikan alternatif juga dikemukakan oleh Bansal et al (2005) bahwa kemenarikan alternatif atau daya tarik pesaing adalah tersedianya alternatif jasa atau barang yang sejenis yang dapat menarik perhatian pelanggan. Apabila pesaing dirasa lebih menarik dan memuaskan, maka konsumen akan berpindah ke layanan yang lebih menarik, lebih dapat dipercaya, atau dapat menyediakan kualitas lay anan yang lebih tinggi.

Penulis berpendapat bahwa adanya proses daya tarik pesaing, ditimbulkan karena adanya dorongan dari dalam diri konsumen bahwa produk yang ditawarkan pesaing lebih menarik dari produk yang sebelumnya digunakan. Seperti yang disampaikan oleh Powell (dalam Afandi 2008:70) yang menjelaskan bahwa prinsip-prinsip daya tarik produk merupakan perwujudan dari mutu produk yang sangat baik. Dimana dapat dikatakan bahwa mutu atau kualitas produk dapat menentukan keadaan dan keberadaan suatu produk. Jika mutu dari suatu produk itu jelek maka daya tarik suatu produk tersebut akan rendah, sebaliknya jika mutu dari suatu produk itu bagus maka daya tarik suatu produk tersebut akan tinggi. Hal ini dikarenakan daya tarik merupakan sesuatu yang sangat penting bagi sebuah produk. Sedangkan menurut Jones (2000) menyatakan bahwa kemenarikan alternatif adalah alternatif lain yang dapat memberikan kualitas yang hampir sama dengan apa yang ditawarkan. Kemenarikan alternatif merupakan aspek yang dapat mempengaruhi persepsi pelanggan untuk berpindah ke penyedia alternatif karena adanya barang atau jasa alternatif yang memiliki kualitas yang sama atau lebih baik. Dan hal tersebut mempengaruhi perilaku 
perpindahan pelanggan dari produk lama ke produk baru. Maka, dapat dikatakan bahwa kemenarikan alternatif mengacu pada persepsi pelanggan mengenai sejauh mana alternatif yang bersaing tersedia di pasar. Oleh sebab itu, perusahaan harus mampu menguasai dan memahami persepsi pelanggan di pasar dengan mempertahankan citra produknya atau mutu produknya agar konsumen bisa tetap loyal dan tidak melakukan perpindahan. Hal ini berarti bahwa sangat penting bagi perusahaan untuk mempertahankan imagenya di kalangan konsumen.

Menurut Simamora (2004) mengatakan bahwa image adalah persepsi yang relative konsisten dalam jangka panjang (enduring perception). Jadi tidak mudah untuk membentuk image atau citra, bila terbentuk sulit untuk mengubahnya. Citra terhadap merek atau produk berhubungan dengan sikap yang berupa keyakinan dan preferensi terhadap suatu merek atau produk tersebut. Jadi, menurut Setiadi (2003) bahwa konsumen yang memiliki citra yang positif terhadap suatu produk, akan lebih memungkinkan untuk melakukan pembelian.

Dalam hal ini , Simamora (2004) membagi komponen image atau citra produk ada tiga diantaranya : Citra pembuat adalah sekumpulan asosiasi yang dipersepsikan konsumen terhadap perusahaan yang membuat suatu produk atau jasa; citra pemakai adalah sekumpulan asosiasi yang dipersepsikan konsumen terhadap pemakai yang menggunakan suatu barang atau jasa yaitu meliputi pemakai itu sendiri, gaya hidup/kepribadian, serta status sosialnya; citra produk adalah sekumpulan asosiasi yang dipersepsikan konsumen terhadap suatu produk yang meliputi atribut produk tersebut, manfaat bagi konsumen, penggunaanya serta jaminan yang diberikan. Dari komponen diatas tersebut, penulis simpulkan bahwa kemenarikan alternatif adalah karakteristik positif yang dimiliki oleh produk pesaing melebihi produk lama. Sehingga, perlu bagi perusahaan untuk membangun atau mengembangkan kualitas produknya dengan mempertahankan brand image di mata konsumen. Maka, untuk mendukung pendapat penulis tersebut Schiffman dan Kanuk (2010) menyebutkan faktorfaktor pembentuk brand image adalah sebagai berikut :

a. Kualitas atau mutu berkaitan dengan kualitas produk yang ditawarkan oleh perusahaan. Hal ini menjadi salah satu aspek yang mempengaruhi daya tarik pesaing.

b. Dapat dipercaya atau diandalkan artinya konsumen akan mempercayai dan mengandalkan produk yang dianggapnya lebih memuaskan.

c. Kegunaan atau manfaat yang terkait dengan fungsi dari suatu produk yang bisa dimanfaatkan oleh konsumen.

d. Pelayanan yang berkaitan dengan tugas perusahaan dalam melayani konsumennya.

e. Resiko berkaitan dengan untung rugi yang dialami oleh konsumen dalam menggunakan produk.

f. Harga dalam hal ini berkaitan dengan tinggi rendahnya atau banyak sedikitnya jumlah uang yang dikeluarkan konsumen untuk mempengaruhi suatu produk, juga dapat mempengaruhi citra jangka panjang.

g. Image yang dimiliki merek itu sendiri yaitu berupa pelanggan, kesempatan dan informasi yang berkaitan dengan suatu merek dari produk tertentu.

Berdasarkan teori-teori tersebut dapat penulis simpulkan juga bahwa kemenarikan alernatif adalah suatu keadaan di mana konsumen memiliki pilihan untuk beralih ke produk lain karena alternatif yang ditawarkan produk lain lebih banyak dan memiliki kualitas yang sama atau lebih. Jadi, dapat memicu perilaku pelanggan untuk beralih ke produk lain, sedangkan jika alternatif atau pesaing rendah maka kemungkinan pergeseran perilaku konsumen akan berkurang bahkan tidak ada terjadi pergeseran. Sehingga Papalapu (2015) menyatakan bahwa faktor penarik yang terdiri dari kemenarikan alternatif dapat mempengaruhi perilaku perpindahan konsumen. Sama persis dengan pendapat Zhang (2012) menyebutkan bahwa kemenarikan alternatif berpengaruh terhadap perilaku 
perpindahan atau niat beralih konsumen. Dalam penelitian ini hanya menggunakan 5 indikator dari 7 indikator kemenarikan alternatif yang dikemukakan oleh Ramada (dalam Wibowo,2013) adalah sebagai berikut : reputasi produk yang dimiliki pesaing, kelengkapan layanan produk yang dimiliki produk pesaing, kualitas layanan sms dan telepon produk yang dimiliki produk pesaing, kualitas jangkauan atau jaringan produk yang dimiliki produk pesaing, kualitas harga produk yang dimiliki produk pesaing.

\section{Biaya Berpindah}

Biaya berpindah adalah biaya yang harus dikeluarkan pembeli apabila berpindah dari poduk pemasok tertentu ke produk pemasok lainnya yang berupa biaya latihan, biaya peralatan, dan biaya desain ulang. Apabila biaya berpindah yang diperlukan cukup besar, maka pesaing yang baru harus mampu memberikan penawaran lebih menarik dibandingkan dari produk sebelumnya terutama menyangkut harga (Umar, 2001:80).

Pandangan lain mengenai biaya berpindah merupakan biaya yang dikeluarkan oleh pelanggan bila berpindah dari produk yang biasa dipakainya ke produk lain yang dibuat oleh perusahaan lain. Misalnya biaya pelatihan kepada karyawan karena penggantian sistem komputer, keterlambatan produksi karena pengujian bahan tertentu, dan lain sebagainya. Hal ini juga merupakan hambatan masuk untuk perusahaan baru karena harus mengatasi biaya ini untuk menguasai pasar (Jopie, 2007: 258). Dari dua pandangan tersebut, menurut penulis juga bahwa biaya berpindah adalah resiko yang harus ditanggung konsumen jika ingin berpindah. Dan seperti yang disampaikan menurut Whitten dan Wakefield (dalam setiarini et al , 2018:33) bahwa biaya berpindah menunjukkan suatu resiko, investasi, dan kehilangan pelanggan dengan perpindahan konsumen dari suatu merek tertentu ke merek lain atau dari penyedia jasa tertentu ke penyedia jasa lainnya.

Setiarini (2018:34) juga mengatakan bahwa ada beberapa studi yang menjelaskan bahwa biaya berpindah meliputi kehilangan financial, waktu, psikologis dan hubungan yang dirasakan konsumen ketika berpindah ke penyedia lainnya. Hal itu biasanya dirasakan oleh pelanggan ketika beberapa waktu kemudian setelah berpindah. Sehingga kepercayaan kepada produk serta proses perhatian dan pemahaman kepada produk baru mulai dikuasai oleh pelanggan.

Biaya berpindah menjadi penting menurut Feick et al (2001: 45) yaitu ketika terdapat banyak perusahaan di dalam pasar dan biaya untuk melakukan perpindahan sangat rendah maka pelanggan cenderung untuk beralih ke produk dari perusahaan yang satu ke produk perusahaan yang lain. Sehingga hal ini menunjukkan tidak adanya sikap loyalitas konsumen terhadap produk yang telah dipakai sebelumnya. Dan sebaliknya jika biaya berpindah tinggi, maka pelanggan akan cenderung untuk tetap loyal terhadap produk lama.

Feick et al (2001: 46) juga mengemukakan bahwa biaya berpindah adalah bentuk pengorbanan yang harus dilakukan oleh pelanggan. Pengorbanan tersebut meliputi : biaya atas waktu artinya saat melakukan perpindahan butuh waktu untuk menguasasi dan memahami penggunaan produk; biaya atas usaha artinya saat melakukan perpindahan butuh usaha untuk mendapatkan produk; biaya atas resiko artinya saat melakukan perpindahan akan mengalami kerugian baik kecil maupun besar untuk memiliki produk.

Burnham et al (2003) menyatakan bahwa tipologi dari biaya berpindah terdiri dari tiga dimensi, antara lain : biaya finansial adalah biaya yang menyebabkan terjadinya kerugian pada sumber daya finansial yang dapat diukur; biaya prosedural merupakan semua biaya pengeluaran yang berhubungan dengan waktu dan usaha; biaya relasional adalah biaya yang menimbulkan ketidaknyamanan secara psikologis dan disebabkan oleh hilangnya identitas dan putusnya ikatan emosional. Pendapat yang dikemukakan oleh Jones (2007) juga mengatakan bahwa biaya berpindah merupakan pengorbanan atau hukuman yang dirasakan oleh konsumen ketika melakukan pergantian salah satu layanan jasa ke layanan jasa lainnya. Selain itu, menurut Xavier (2000) menyatakan bahwa biaya berpindah merupakan biaya 
nyata atau yang dirasakan yang timbul sebagai akibat ketika mengubah pemasok tetapi tidak terjadi ketika masih menggunakan pemasok saat ini. Dan juga menurut Pradnyawati (2013) Biaya berpindah dapat saja menyebabkan niat untuk berpindah atau dapat membuat seseorang enggan untuk melakukan perpindahan. Patterson dan Smith (2003) juga mengemukakan bahwa dalam pemasaran jasa terdapat beberapa jenis biaya berpindah yang mempengaruhi niat konsumen untuk beralih ke yang lain yaitu Continuity costs, Learning costs dan Sunk costs. Dalam penelitian ini, indikator yang digunakan untuk mengukur biaya berpindah mengikuti beberapa indikator dari Bawanestri (dalam Wibowo 2013:15) yang menjabarkan indikator dari variabel biaya berpindah sebagai berikut :kualitas produk yang tidak sesuai harapan jika beralih ke produk lain; biaya atas waktu dan usaha untuk mengevaluasi produk lain; biaya atas waktu dan usaha membiasakan diri dengan fitur baru jika beralih ke produk lain; benefit yang hilang jika beralih ke produk lain; biaya atau pengorbanan yang dikeluarkan dalam proses berpindah ke produk lain jika beralih.

Menurut Dantes (2012) Hipotesis adalah praduga atau asumsi yang harus diuji melalui data atau fakta yang diperoleh dengan jalan penelitian. Berdasarkan nalar konsep dasar dan kerangka pemikiran sebagaimana dinyatakan tersebut diatas, hipotesis yang dirumuskan dalam penelitian ini adalah:

$\mathrm{H}_{1}$ : Ada pengaruh kemenarikan alternatif terhadap niat beralih

$\mathrm{H}_{2}$ : Ada pengaruh biaya berpindah terhadap niat beralih

\section{MODEL PENELITIAN}

Berdasarkan latar belakang masalah dan landasan teori yang telah disebutkan di atas, maka kerangka sebagai dasar dalam mengarahkan pemikiran untuk mengetahui sejauh mana pengaruh faktor penarik yang berasal dari produk lainnya berupa kemenarikan alternatif dan faktor penghambat yaitu biaya berpindah sebagai faktor yang dapat memperkuat atau memperlemah suatu niat untuk beralih. Penggunaan variabel-variabel ini lebih tepat untuk mengukur intensi perpindahan konsumen atau niat beralih pada pengguna kartu XL Axiata. Oleh karena itu, dalam kerangka konseptual peneliti menggunakan variabel (X1) yakni kemenarikan alternatif, variabel (X2) adalah biaya berpindah dan variabel (Y) adalah niat beralih. Untuk lebih jelasnya, maka berikut adalah kerangka konseptualnya :

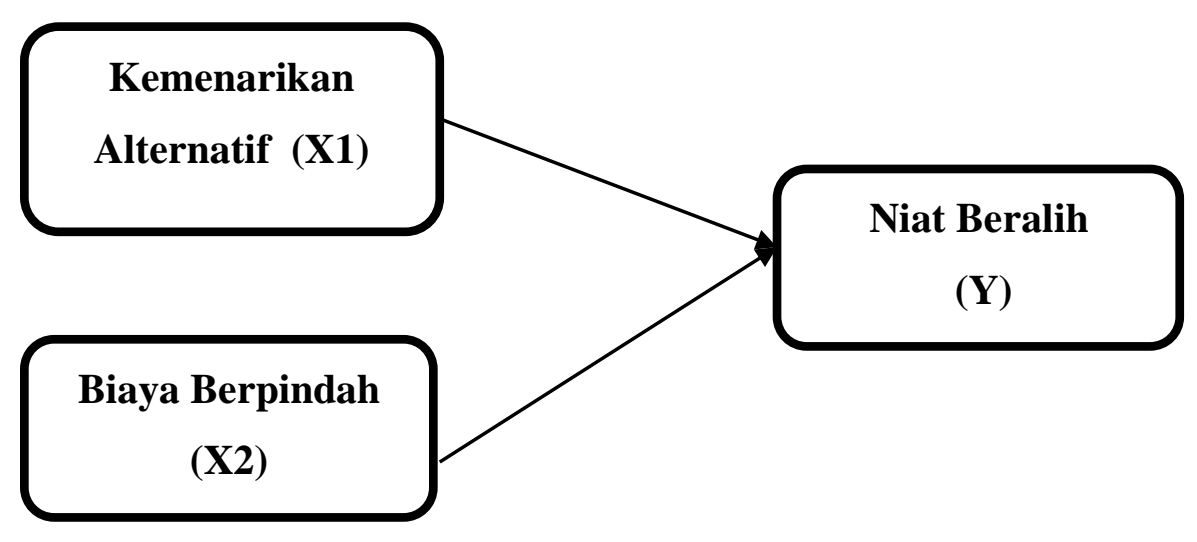

Gambar 1. Kerangka Pikir Penelitian

\section{METODE PENELITIAN}

Populasi dan Sampel

Populasi adalah suatu wilayah generalisasi yang terdiri atas objek atau subjek dan memiliki kualitas dan karakteristik tertentu yang ditetapkan oleh peneliti untuk dipelajari dan kemudian ditarik kesimpulannya. Jadi, populasi bukan hanya orang, tetapi juga objek dan 
benda-benda alam lainnya. Populasi juga bukan hanya sekedar jumlah yang ada pada subjek yang dipelajari, tetapi meliputi seluruh karakteristik atau sifat yang dimiliki oleh objek ataupun subjek (Sugiyono, 2007:115). Dalam penelitian ini populasinya adalah semua mahasiswa Universitas Kristen Artha Wacana Kupang yang menjadi pengguna kartu XL Axiata.

Sampel adalah bagian dari jumlah dan karakteristik yang dimiliki oleh populasi tersebut. Bila populasi besar, dan peneliti tidak mungkin mempelajari semua yang ada pada populasi. Misalnya karena keterbatasan dana, tenaga dan waktu maka peneliti dapat menggunakan sampel yang diambil dari populasi tersebut (Sugiyono, 2007:116). Teknik pengambilan sampel yang digunakan oleh penulis dalam penelitian ini adalah metode judgement sampling yaitu sampel yang diambil sesuai dengan karakteristik populasi yang diinginkan. Jumlah sampel yang layak untuk penelitian ini adalah sebanyak 100 orang responden.

\section{Teknik Analisis Data}

Analisis regresi berganda adalah alat untuk meramalkan nilai pengaruh dua variabel bebas atau lebih terhadap satu variabel terikat. Yang bertujuan untuk membuktikan ada tidaknya hubungan fungsional atau hubungan kausal antara dua atau lebih variabel bebas (Buwono, 2005:43).

Rumus regresi linier berganda:

$$
\mathbf{Y}=\mathbf{a}+\mathbf{b}_{1} \mathbf{X}_{1}+\mathbf{b}_{2} \mathbf{X}_{2}+\mathbf{e}
$$

Dimana:

$\mathrm{Y}=$ Niat Beralih

$\mathrm{a}=$ Konstanta

$\mathrm{b}_{1}=$ Koefisien regresi kemenarikan alternatif

$\mathrm{X}_{1}=$ Kemenarikan Alternatif

$\mathrm{b}_{2}=$ Koefisien regresi biaya berpindah

$\mathrm{X}_{2}=$ Biaya berpindah

$\mathrm{e}=$ Standar error

\section{HASIL DAN PEMBAHASAN}

\section{Hasil Pengujian}

Untuk mengetahui pengaruh kemenarikan alternatif dan biaya berpindah terhadap niat beralih pengguna kartu XL Axiata digunakan analisis regresi linear berganda dimana variabel bebasnya adalah kemenarikan alternatif (X1) dan biaya berpindah (X2) serta variabel terikatnya adalah niat beralih (Y). Untuk melakukan pengukuran dalam penelitian ini maka digunakan program IBMSPSSv. 16 (statistical productand service solution) for windows. Didapatkan hasil pengujian regresi linier berganda dengan persamaan regresi berdasarkan tabel dibawah ini : 
Tabel 1

Hasil Analisis Regresi Linear Berganda

Coefficients

\begin{tabular}{|c|c|c|c|c|c|c|}
\hline \multirow{2}{*}{\multicolumn{2}{|c|}{ Model }} & \multicolumn{2}{|c|}{ Unstandardized Coefficients } & \multicolumn{2}{|l|}{$\begin{array}{l}\text { Standardized } \\
\text { Coefficients }\end{array}$} & \multirow[b]{2}{*}{ Sig. } \\
\hline & & B & Std. Error & Beta & $\mathrm{t}$ & \\
\hline \multirow[t]{3}{*}{1} & (Constant) & 4.423 & 1.415 & & 3.125 & .002 \\
\hline & $\mathrm{X} 1$ & .358 & .091 & .330 & 3.917 & .000 \\
\hline & $\mathrm{X} 2$ & .367 & .070 & .444 & 5.265 & .000 \\
\hline
\end{tabular}

a. Dependent Variable: $Y$

Sumber : Data primer yang diolah, tahun 2020

Berikut ini adalah persamaan regresinya : $\mathrm{Y}=4,423+0,358 \mathrm{X} 1+0,367 \mathrm{X} 2$. Nilai konstanta sebesar 4,423 artinya jika nilai kemenarikan alternatif (X1) dan biaya berpindah (X2) sama dengan nol, maka niat beralih (Y) memiliki nilai sebesar 4,423. Untuk koefisien regresi (b1) sebesar 0,358 artinya jika kemenarikan alternatif (X1) mengalami kenaikan sebesar $1 \%$, maka niat beralih (Y) akan meningkat sebesar 0,358. Koefisien bernilai positif artinya terjadi hubungan positif antara kemenarikan alternatif (X1) dengan niat beralih (Y). Dengan demikian, semakin tinggi kemenarikan alternatif atau daya tarik positif yang dimiliki operator lain maka semakin tinggi niat pengguna kartu XL Axiata untuk beralih. Sedangkan koefisien regresi (b2) sebesar 0,367 artinya jika biaya berpindah (X2) mengalami kenaikan sebesar 1\%, maka niat beralih (Y) akan meningkat sebesar 0,367. Koefisien bernilai positif artinya terjadi hubungan positif antara biaya berpindah (X2) dengan niat beralih (Y). Dengan demikian, dalam penelitian ini menunjukkan bahwa walaupun semakin tinggi biaya berpindah tidak akan menghambat niat pengguna kartu XL Axiata untuk tetap melakukan perpindahan. Berdasarkan persamaan tersebut, dapat diketahui bahwa nilai koefisien regresi dari variabel kemenarikan alternatif (X1) dan biaya berpindah (X2) memiliki nilai koefisien regresi positif, dimana koefisien (b) untuk variabel kemenarikan alternatif (X1) sebesar 0,358 dan variabel biaya berpindah (X2) sebesar 0,367. Hal tersebut menunjukan bahwa variabel kemenarikan alternatif (X1) dan biaya berpindah (X2) memiliki arah pengaruh yang positif terhadap niat beralih (Y).

\section{Pembahasan}

Berdasarkan hasil dari uraian analisis yang telah dilakukan diatas, maka secara keseluruhan pembahasan hasil penelitian ini adalah sebagai berikut :

\section{Pengaruh Kemenarikan Alternatif Terhadap Niat Beralih Pengguna Kartu XL Axiata}

Dalam penelitian ini, hipotesis pertama menyatakan bahwa Ho:b1=0 artinya tidak ada pengaruh antara kemenarikan alternatif terhadap niat beralih dan $\mathrm{H}_{1}: b 1 \neq 0$ artinya ada pengaruh antara kemenarikan alternatif terhadap niat beralih. Berdasarkan persamaan tersebut, koefisien regresi (b1) sebesar 0,358 artinya jika kemenarikan alternatif (X1) mengalami kenaikan sebesar 1\%, maka niat beralih (Y) akan meningkat sebesar 0,358. Koefisien bernilai positif artinya terjadi hubungan positif antara kemenarikan alternatif (X1) dengan niat beralih (Y). Dengan demikian, semakin tinggi kemenarikan alternatif atau daya tarik positif yang dimiliki operator lain maka semakin tinggi niat pengguna kartu XL Axiata untuk beralih. Selain itu, diketahui bahwa variabel kemenarikan alternatif memiliki nilai sign sebesar 0,000 yang artinya lebih kecil dari 0.05. Dan oleh karena nilai sig. < 0,05 maka Ho $(\mathrm{b} 1=0)$ ditolak dan $\mathrm{Ha}(\mathrm{b} 1 \neq 0)$ diterima yang artinya variabel kemenarikan alternatif (X1) berpengaruh positif terhadap variabel niat beralih (Y). 
Jadi hasil analisis diatas menunjukkan bahwa variabel kemenarikan alternatif berpengaruh positif tehadap niat beralih pengguna kartu XL Axiata. Seperti yang dikemukakan oleh Bansal et al (2005) bahwa kemenarikan alternatif atau daya tarik pesaing adalah tersedianya alternatif jasa atau barang yang sejenis yang dapat menarik perhatian pelanggan. Apabila pesaing dirasa lebih menarik dan memuaskan, maka konsumen akan berpindah ke layanan yang lebih menarik, lebih dapat dipercaya, atau dapat menyediakan kualitas layan an yang lebih tinggi.

Hasil penelitian ini didukung juga oleh penelitian yang dilakukan oleh Papalapu (2015) menyatakan hal yang sama bahwa faktor penarik yang terdiri dari kemenarikan alternatif berpengaruh signifikan terhadap perilaku perpindahan konsumen pada pengguna indovision di Manado. Hasilnya juga sama dengan penelitian yang dilakukan oleh Zhang (2012) menyebutkan bahwa kemenarikan alternatif berpengaruh positif terhadap perilaku perpindahan atau niat beralih konsumen. Selain itu, dalam penelitian Wibowo (2013) juga menyatakan hal yang sama bahwa kemenarikan alternatif berpengaruh signifikan terhadap perpindahan pelanggan.

\section{Pengaruh Biaya Berpindah Terhadap Niat Beralih Pengguna Kartu XL Axiata}

Dalam penelitian ini, hipotesis kedua menyatakan bahwa Ho:b2 $=0$ artinya tidak ada pengaruh antara biaya berpindah terhadap niat beralih dan $\mathrm{H}_{2}: \mathrm{b} 2 \neq 0$ artinya ada pengaruh antara biaya berpindah terhadap niat beralih. Berdasarkan persamaan tersebut, koefisien regresi (b2) sebesar 0,367 artinya jika biaya berpindah (X2) mengalami kenaikan sebesar $1 \%$, maka niat beralih (Y) akan meningkat sebesar 0,367 . Koefisien bernilai positif artinya terjadi hubungan positif antara biaya berpindah (X2) dengan niat beralih (Y). Dengan demikian, dalam penelitian ini menunjukkan bahwa walaupun semakin tinggi biaya berpindah tidak akan menghambat niat pengguna kartu XL Axiata untuk tetap melakukan perpindahan. Selain itu, diketahui bahwa variabel biaya berpindah memiliki nilai sign sebesar 0,000 yang artinya lebih kecil dari 0.05. Oleh karena nilai sig. $<0,05$ maka Ho (b2 $=0)$ ditolak dan $\mathrm{Ha}(\mathrm{b} 2 \neq 0)$ diterima yang artinya variabel biaya berpindah (X2 berpengaruh positif terhadap variabel Niat Beralih (Y).

Jadi hasil analisis diatas menunjukkan bahwa variabel biaya berpindah berpengaruh positif tehadap niat beralih pengguna kartu XL Axiata. Hasil ini sesuai dengan teori yang dikemukakan oleh Jones (2007) dalam penelitiannya mengatakan bahwa biaya berpindah merupakan pengorbanan atau hukuman yang dirasakan oleh konsumen ketika melakukan pergantian salah satu layanan jasa ke layanan jasa lainnya. Pandangan lain yang sama menurut Jopie (2007:258) mengenai biaya berpindah merupakan biaya yang dikeluarkan oleh pelanggan bila berpindah dari produk yang biasa dipakainya ke produk lain yang dibuat oleh perusahaan lain. Selain itu, menuut Xavier (2008) menyatakan bahwa biaya berpindah merupakan biaya nyata atau yang dirasakan yang timbul sebagai akibat ketika mengubah pemasok (supplier) tetapi tidak terjadi ketika masih menggunakan pemasok saat ini. Dan juga menurut Pradnyawati (2013) Biaya berpindah dapat saja menyebabkan niat untuk berpindah atau dapat membuat seseorang enggan untuk berpindah.

Hasil penelitian ini didukung juga oleh penelitian yang dilakukan oleh Papalapu (2015) menyatakan hal yang sama bahwa faktor penghambat yaitu biaya berpindah berpengaruh signifikan terhadap perilaku perpindahan konsumen pada pengguna indovision di Manado.Sama halnya dengan penelitian Wibowo (2013) menyatakan bahwa kemenarikan alternatif, biaya berpindah, hubungan interpersonal, dan pemulihan layanan berpengaruh signifikan terhadap perpindahan pelanggan atau niat untuk beralih. 


\section{PENUTUP}

\section{Kesimpulan}

Berdasarkan hasil penelitian diatas, maka peneliti dapat mengemukakan beberapa hal penting sebagai berikut :

a. Berkaitan dengan kemenarikan alternatif yang dimiliki operator lain dapat memberikan pengaruh kepada konsumen untuk beralih dari produk XL Axiata kepada produk dari operator kartu seluler lainnya. Maka PT. XL Axiata tbk sebaiknya memperbaiki kualitas jangkauan jaringan produknya dengan terus melakukan inovasi dan strategi-strategi bersaing agar dapat unggul dalam bersaing. Apabila pesaing dirasa lebih menarik dan memuaskan, maka konsumen akan berpindah ke layanan yang lebih menarik, lebih dapat dipercaya, atau dapat menyediakan kualitas layanan yang lebih tinggi. Jika mutu dari suatu produk itu jelek maka daya tarik suatu produk tersebut akan rendah, sebaliknya jika mutu dari suatu produk itu bagus maka daya tarik suatu produk tersebut akan tinggi. Hal ini dikarenakan daya tarik merupakan sesuatu yang sangat penting bagi sebuah produk. Oleh sebab itu, perusahaan harus mampu menguasai dan memahami persepsi pelanggan di pasar dengan mempertahankan citra produknya atau mutu produknya agar konsumen bisa tetap loyal dan tidak melakukan perpindahan. Hal ini berarti bahwa sangat penting bagi perusahaan untuk mempertahankan imagenya di kalangan konsumen.

b. Dalam penelitian ini ditemukan bahwa walaupun biaya berpindah lebih mahal dari saat memakai produk XL Axiata, tidak menjadi penghambat bagi konsumen untuk tetap melakukan perpindahan karena reputasi operator lain, kualitas layanan dan jangkauan jaringan yang diberikan sesuai dengan harga yang ditawarkan. Oleh karena itu, PT XL Axiata tbk perlu memperluas lagi jangkauan jaringannya dan meningkatan reputasinya dengan cara menjaga kepercayaan konsumen bahwa XL Axiata sebagai pelopor layanan selular kepada anggota masyarakat biasa di Indonesia melalui program tarif hemat -Rp1/detik yang memungkinkan lebih banyak penduduk berpenghasilan menengah ke bawah menikmati layanan telepon selular dengan infrastruktur jaringan dan layanan yang sangat luas di seluruh pelosok tanah air termasuk provinsi Nusa Tenggara Timur.

\section{DAFTAR PUSTAKA}

Arifin, Johar. 2017. SPSS 24 untuk penelitian dan skripsi. PT. Elex Media Komputindo. Jakarta

Afandi, Pandi. 2008. Analisis Faktor Penentu Daya Tarik Produk Pada Pasar UKM Lopait Kecamatan Tuntang Kab. Semarang. Among Makarti, Vol. 1, No.2.

Ariani, Desti. 2012. Pengaruh Elemen-elemn Brand Equity terhadap Keputusan Perpindahan Merek Provider Kartu GSM Prabayar di Indonesia tahun 2008-2012. Skripsi Institut Manajemen Telkom.

Bansal, H.S., Taylor, S.F. and James, Y.S. 2005. "Migrating to New Service Providers: Toward a Unifying Framework of Consumers' Switching Behaviors". Journal of Academy of Marketing Science. Vol. 33 (1): 96-115.

Burhan Bungin.2006.Analisis Data Penelitian Kualitatif.Jakarta : Raja Grafindo.

Burnham, T. A., Krels, Judy K \& Vijay Mahajan. 2003. Consumer Switching Cost: A typology, antecedents, and consequences. Academy of Marketing Science.31 (2). pg. 109 
Bursa Efek Indonesia.2019.(online). Diakses pada tanggal 2 Juli 2020 melalui https://databoks.katadata.co.id/datapublish/2020/01/23/telkomsel-raja-operatorseluler-indonesia

Buwono, Agung Nugroho.2005.Strategi jitu memilih metode statistic Penelitian dengan SPSS.Penerbit,Abdi. Yogyakarta

Churchill Jr, Gilbert A.2005.Dasar-Dasar Riset Pemasaran Edisi 4 Jilid 1.Terjemahan oleh Andrianty, Dwi K. Yahya dan Emil Salim.(Suryadi Saat dan Wisnu C. Kristiaji,eds).Jakarta (ID):Erlangga.

Colgate, Mark., and Bodo Lang. 2001. Switching Barriers in Consumer Markets: An Investigation Of The Financial Services Industry. The Journal of Consumer Marketing, 18(4):332-347.

Dantes, Nyoman. 2012.Metode Penelitian. Yogyakarta: ANDI

Hatta, Iha Haryani dan Setiarini. 2018. "Pengaruh Word Of Mouth dan Switching Cost Terhadap Keputusan Pembelian dan Loyalitas.

Jaya, Lukito. 2016. Faktor - Faktor yang Mempengaruhi Customers Switching Behavior Dalam Industri Retail Banking Pada Bank BCA. Jurnal Bisnis dan Manajemen. Vol. 52. No. 11 . Hlm. 114-141

Jones. 2000. Switching Barrier dan Niat Pembelian Kembali Dalam Layanan (Switching Barrier and repurchase intention in services). Journal of Retailing. Hal 259-274.

Jones, Michael A. 2007. The Positive and Negative Effects of Switching Costs on Relational Outcomes. Journal of Service Research. Vol. 9. No. 4. Pages: $335-355$

Julander,C.R.,Ragnar Soderberg dan Magner Soderlund. 2003. Pengaruh Switching Barriers pada Kepuasan, Niat Pembelian Kembali dan Loyalitas Sikap. Sekolah Ekonomi Stockholm.

Jusuf, Jopie. 2007. Analisis Kredit untuk Account Officer. PT Gramedia Pustaka Utama, Jakarta.

Keaveney, S. M. dan Parthasarathy, M. 2001. "Customer Switching Behavior in Online Services: An Exploratory Study of the Role of Selected Attitudinal, Behavioral, and Demographic Factors",Journal of the Academy of Marketing Science, Vol. 29 No. 4, pp.374-390.

Lee, J., J. Lee and L. Feick. 2001. "The Impact of Switching Costs on the Customer Satisfaction-loyalty Link: Mobile Phone Service in France”. Journal of Services Marketing, Vol. 15 No. 1, pp. 35-48.

Papalapu, Bill Jezy Nico. 2015. "Pengaruh Push, Pull Dan Mooring Terhadap Perilaku Beralih Konsumen (Studi Kasus Pada Konsumen Indivision Manado).

Patterson, P.G. and Smith, T. 2003. - A Cross Cultural Study of Switching Barriers and Propensity to Stay With Service Providers\|, Journal ofRetailing, Vol. 79, pp. 107120. 
Pradnyawati dan Suasana, 2013. Pengaruh Switching Cost dan Switching Intention terhadap Word-Of-Mouth Pada Konsumen Provider Seluler Telkomsel di Kota Denpasar.

Priyatno Dwi. 2009. Mandiri Belajar SPSS. Mediakom. Yogyakarta

Reichheld, F.F. 1996. The Loyalty Effect, Harvard Business School Press, Boston, MA.

Schiffman dan Kanuk. 2010. Perilaku Konsumen. Jakarta: PT. INDEK.

Setiadi, N. J.2003. Perilaku Konsumen: Konsep dan Implikasi untuk Strategi dan Penelitian Pemasaran. Jakarta: Prenada Media

Setiani, Candra. 2019. Pengaruh Push - Pull - Mooring Factors (Ppm) Terhadap Customers Switching Intention Dari Bank Konvensional Ke Bank Syariah (Studi Kasus Pada Masyarakat Desa Sumogawe, Kecamatan Getasan, Kabupaten Semarang). Skripsi IAIN-Salatiga.

Siagian dan Sugiarto,2006.Metode Statistika Untuk Bisnis Dan Ekonomi.PT Gramedia Pustaka Utama.Jakarta

Siddiqui, DR Kamran. 2011. Personality Influence Consumers Switching. Journal of Contemporary Research In Businss: Vol.2 No. 10 pages 363-370.

Simamora, Bilson. 2004. Panduan Riset Perilaku Konsumen. Jakarta: PT.Gramedia Pustaka Utama.

Sugiyono. 2007. Metoda Penelitian Administrasi dilengkapi dengan Metode R\&D. Bandung. Alfabeta.

Sulistyani. 2006. Analisis Perilaku Brand Switching Produk Air Minum Mineral di Daerah Istimewa Yogyakarta. Jurnal Akuntansi dan Manajemen. STIE YKPN.

Taufiq.2007 "Pengaruh Switching Barrier terhadap Repurchase Intention (studi kasus pada produk pemutih wajah merek Pond's di swalayan "RATU" Malang).Skripsi UIN Malang.

Umar, Husein.2001. Strategic Management In Action. PT Gramedia Pustaka Utama. Jakarta.

Wibowo. 2013. Analisis pengaruh Switching Cost, Attractiveness of Alternative, Interpersonal Relationship dan Service Recovery terhadap Repurchase Intention GSM XL prabayar. Jakarta.

Widiyanto,Ibnu. 2008. Pointers: Metodologi Penelitian. BP Undip,Semarang

Xavier, Patrick, adn Damitri Yosilanti. 2000. Switching Cost and Consumer Behavior : Implication for telecommunications Regulation. Digital Policy Regulation and Govermance. Vol. 10. No. 4. Pages : 13 - 29

Z.K. Zhang, et all. 2012. Online Service Behavior: The Case of Blog Service Provider. Journal of Electronic Commerce Research, Vol. 13, No. 3 